\title{
Technology Literation: The Effect on Quality of Learning in Elementary School of Lentera Hati Islamic Boarding School
}

\author{
Husnul Faizah ${ }^{1}$, A Wahab Jufri ${ }^{1}$, Dadi Setiadi ${ }^{1}$ \\ ${ }^{1}$ University of Mataram \\ 62 Jl. Majapahit, Mataram, NTB, Indonesia
}

DOI: $10.22178 /$ pos.61-5

LCC Subject Category:

LB1603-1696.6

Received 24.07.2020

Accepted 28.08.2020

Published online 31.08.2020

Corresponding Author:

Dadi Setiadi setiarasyid@gmail.com

(C) 2020 The Authors. This article

is licensed under a Creative Commons

Attribution 4.0 License @ (1)
Abstract. This study aimed to determine the effect of technological literacy on the quality of learning in the primary school of Lentera Hati Islamic boarding school. This research is a quantitative research with an ex post facto approach. The population of this study consists of all 22 primary school teachers in Lentera Hati Islamic boarding school, who also serve as research samples. Observations, documentation, and questionnaires were performed for data collection. Data were analyzed using partial regression analysis and multiple regression techniques. The results showed that there was a positive and significant influence between technological literacy on the quality of learning at the primary school of Lentera Hati Islamic boarding school. This is evident from the correlation coefficient rx1y value of 0723 and the determination coefficient $r^{2} \times 1 y$ value of $31.1 \%$, so the higher the technological literacy, the higher the quality of learning.

Keywords: technology skill; Learning quality; Islamic Boarding School.

\section{INTRODUCTION}

The development of information and communication technology has had an impact on the educational world, especially in the learning process [7]. So that interactions between teachers and students not only take place through personal relationships but also take place using information and communication technologies such as telephone, computer, internet, e-mail, etc. Teachers can provide services without dealing directly with students [26]. Likewise, students can obtain extensive information and knowledge from various sources via cyberspace or the internet [11]. With the inclusion of information and communication technology materials in the curriculum, the role of information and communication technology has a very important position as one of the learning media.

The latest information and communication technology make it possible to improve the quality of education, interactive educational software is a way to enrich education by integrating technology into traditional classrooms [10]. Also, technology is a good resource for teachers to support the teaching and learning process. The teacher, therefore, faces more complex challenges. Teachers in the classroom deal with students with different characters, challenging learning materials, learning processes that are consistent with the standards and requirements for students' ability to think more critically. This is due to the rapid development of science and technology, changes in demography, globalization, and the environment that have a major impact on teacher training and professionalism [12]. In the 21st century, this shift in education model began to emerge from the traditional education model that relies on face-toface or face-to-face and transitions to an online education system. To bring about the impact of challenging changes, the birth of the term home education, independent learning, and distance learning.

The learning process is not only about the classroom, but also uses technology such as digital media, internet, and teleconferences. In response, teachers should always try to motivate themselves in the use and mastery of technology. So that these efforts cannot be separated from the term literacy itself, which is understanding and learning about the technology. In addition to the demands of the development of scientific and technological progress and changes in social life 
and globalization, changes in the curriculum of schools in schools are things that must be done to strengthen technology skills by teachers [21]. The importance of literacy in information and communication technology is an attempt to meet global challenges. So that the role of education becomes the spearhead of shaping high-quality human resources, namely people who can handle time as they enter the era of the industrial revolution.

The education sector should receive intensive attention, treatment, and priorities from government, community, and education management parties, such as training teachers to improve technology skills. Subsequently, it is expected that enhancing technological literacy can improve the quality of education. Efforts to improve the quality of education as a whole include improving the quality or quality of learning, including renewing approaches or increasing the relevance of teaching methods [27].

During development, literacy expanded the meaning and scope of various aspects. Literacy is not only limited to reading, writing, and math but extends to other areas such as technology, media, economic and financial literacy, and others. The meaning of literacy depends on the field that follows it. The author [14] states that another term related to literacy is e-literacy. E-literacy is the ability to use information technology devices to adapt to time. In addition to development, other terms have emerged, such as technological literacy and computer literacy and internet literacy. Looking at the level of use of information and communication technology, based on the results of a survey by the Indonesian Internet Service Providers Association (in Indonesia called APJII) in 2018, there was an increase in internet users in Indonesia from 171 million users in 2017 to 171 , 17 million users in 2018 (APJII, 2018). Based on this data, 91\% of internet users in Indonesia are 15-19 years old in 2018. This shows that most students in Indonesia are no stranger to the internet and its use.

The author [24] shows that the use of media technology in learning has a positive and significant effect on the quality of learning. The use of technological applications in learning has been proven to improve learning outcomes. Similarly, [13] concluded in his study that the skills of VII grade high school students improved after using technologybased learning. An attempt to improve the quality of students' process and learning outcomes, including by increasing the ability of teachers to use technology applications in the learning process and evaluation of learning outcomes, is technology skill [18].

Technology literacy is the ability to use technology and information applications effectively and efficiently in different contexts, such as academia and education, learning and teaching, learning evaluation, career, and everyday life [1]. The use of technology and communication in the field of education offers every learning opportunity the opportunity to access learning materials that are offered in an interactive form via a computer network [16]. Especially in primary schools in low grades (grades 1, 2, and 3) the use of information and communication technology is very useful in terms of the supply of material. The use of visualization and animation is expected to increase student understanding. In addition to primary school teachers, there are classroom teachers who must master all subjects except religious subjects and physical education [28]. In this way, primary school teachers should be more creative and innovative due to the different characteristics of each subject. The types of sources and learning media are based on information and communication technology that can be used by primary school teachers, among others, in the learning process: (1). Computers (2). LCD (3). Internet (4). Learning $\mathrm{CD}$, (5) email (6). Percentage of power points (7) Multimedia. Much software can be developed into interesting learning media. Primary school children in the learning process are still learning while playing, so they should use educational games during the learning process. Show animation when explaining scientific material, such as showing the blood flow process, the breathing process. By using educational games when learning math, learning will be interesting. By using technological media in the learning process, students become excited to learn [23].

As educators, teachers should have the ability to design learning scenarios, implement them, and conduct assessments. To be able to learn well to achieve maximum success, teachers must be able to prepare teaching materials [3]. The instructional media prepared by the teacher must be adapted to technological progress, the teacher must prepare not only manual media in the form of graphs but also varied and equipped with digital media. To this end, a survey was conducted in the form of providing questionnaires with infrastructure indicators, the ability of teachers to use information and communication technology in 
teacher learning, and the evaluation of information and communication technology.

Based on the results of the research or observation of the availability of information and communication technology, the ability of teachers to use technology in learning has been fulfilled and implemented. However, some teachers do not learn to use information and communication technology, especially in the low class (classes I, II, and III). The teacher focuses more on the use of information and communication technology in the upper class. Also, the ability to use information and communication technology in the form of a projector LCD still relies on the help of other teachers. This certainly shows the lack of competence of teachers in the use of technology. In the primary school of Lentera Hati Islamic boarding school is an educational institution by promoting a modern technology-based learning system. This means that teachers with such learning conditions are, of course, necessary to understand and master technological literacy.

The learning process in the primary school of the Lentera Hati Islamic boarding school that emphasizes the motto 'character, modern, intelligent and Islamic' is an attempt to improve the quality of learning in the primary school of Lentera Hati Islamic boarding school. So that the expectations of all parties, including the government, society, and parents of students, about learning patterns for students or students at the primary school of Lentera Hati Islamic boarding school are prepared as the next generation of quality and can adapt to life socially, nationally and state. This research was therefore conducted under the title Effect of Technology Literacy on Learning Quality in the Elementary School of Islamic Boarding School Lentera Hati.

\section{METHOD}

This research is a quantitative study, a research method based on the philosophy of positivism used to investigate a particular population or sample, data collection using research tools, quantitative or statistical data analysis, to test a predetermined hypothesis. This study uses an ex post facto approach. Ex post facto research is research that searches for cause-effect relationships that are not manipulated or treated by researchers [17].

The population of this study consists of all teachers of the primary school in Lentera Hati Islamic boarding school with 22 teachers. Since the total population is 22 teachers, this study was performed on the entire population (total sample). So that the sample of this study were all teachers in the primary school of Lentera Hati Islamic Boarding School.

The data collection techniques in this study used observation, documentation, and questionnaires. A questionnaire (questionnaire) is a data collection technique done by providing a series of questions or written statements to respondents to be answered [22]. In this study, the types of instruments used were open and closed questionnaires about technological literacy and learning quality variables and the use of a Likert scale with grades and assessment scores, namely: 1) Always a score of $4 ; 2$ ) Often a score of 3 ; 3) Sometimes graded 2; 4) Never scored 1.

Data analysis techniques in this study used partial regression analysis techniques and multiple regression. Required tests such as the normality test, linearity test, multicollinearity test, and heteroscedasticity test were previously performed. After you know that the data is normally distributed and meets the requirements of the analysis test, the next step is to test the hypothesis with partial regression analysis and multiple regression. Adjusted $r^{2}$ calculation results are used to find out what percentage of the contribution of the influence of independent variables (technological literacy) to the dependent variable (learning quality).

\section{RESULTS AND DISCUSSION}

Technology Literacy Variable Data Descriptions. The targeted technological literacy includes technological knowledge, technical skills and interests, and attitudes. Data for technological literacy variables were obtained from the results of questionnaires completed by 22 primary school teachers of Lentera Hati Islamic boarding school, with 16 question items. The data on technological literacy is thus presented in Table 1.

Table 1 shows that the distribution of the level of technological literacy of teachers in the primary school of Lentera Hati Islamic Boarding School into the very high teacher of category $1(4.5 \%)$, teachers of high category 2 (9\%), teachers of average category $17(77.3 \%)$, and a low category of 2 teachers $(9 \%)$ with an average level of distribution of the indicator values shown in Figure 1. 
Table 1 - Distribution of Respondent Learning Quality Levels

\begin{tabular}{|l|c|c|c|}
\hline Interval & Frequency & Percentage & Category \\
\hline $90-100$ & 1 & 4,5 & Very high \\
\hline $80-89$ & 2 & 9 & High \\
\hline $65-79$ & 17 & 77,3 & Moderate \\
\hline $55-64$ & 2 & 9 & Low \\
\hline $0-54$ & - & - & Very low \\
\hline Total & 22 & 100.0 & \\
\hline
\end{tabular}

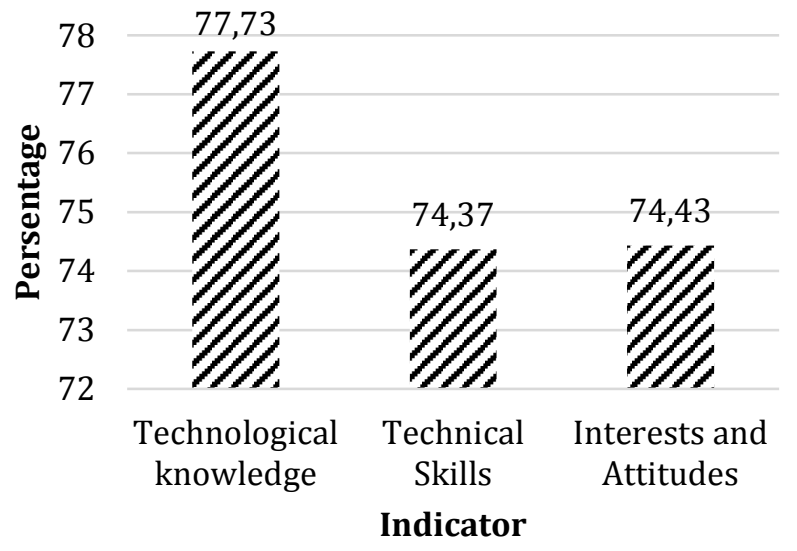

Figure 1 - Distribution of Average Value of Technology Literacy Indicators

The data in Figure 1 shows that the technical skill indicator has a different mean value. The technology knowledge indicator with the highest rating is an indicator of technological knowledge with an average value of 77.73 . While the indicator with the lowest rating is an indicator of technical skills with an average of 74.37. Therefore, it can be concluded that the three indicators of technological literacy are categorized as moderate, so implementation is still not optimal.

Description of Learning Quality Variables. Data for learning quality variables were obtained from the results of questionnaires completed by 22 teachers in the primary school of the Lentera Hati Islamic boarding school, with 19 items of question items. The results of each score from the measure to the question items are then tabulated so that they are data ready for statistical processing. Learning quality data is presented in the categories Very High, High, Medium, Low, Very Low. The data of learning quality is therefore presented in Table 2.

Table 2 shows that the distribution of the level of respondents to the quality of learning is very high, 5 teachers $(22.7 \%), 11$ teachers $(50 \%)$ in the high category, 6 teachers $(27.3 \%)$ in the medium category.

Table 2 - Distribution of Respondent Learning Quality Levels

\begin{tabular}{|l|c|c|c|}
\hline Interval & $\begin{array}{c}\text { Frequenc } \\
\mathrm{y}\end{array}$ & $\begin{array}{c}\text { Percentag } \\
\mathrm{e}\end{array}$ & Category \\
\hline $90-100$ & 5 & 22,7 & Sangat Tinggi \\
\hline $80-89$ & 11 & 50 & Tinggi \\
\hline $65-79$ & 6 & 27,3 & Sedang \\
\hline $55-64$ & - & - & Rendah \\
\hline $0-54$ & - & - & $\begin{array}{c}\text { Sangat } \\
\text { Rendah }\end{array}$ \\
\hline Total & 22 & 100.0 & \\
\hline
\end{tabular}

This means that the quality of learning both plannings, implementing, and evaluating learning by looking at the average distribution is quite effective with the level of distribution of the average indicator values presented in Figure 2.

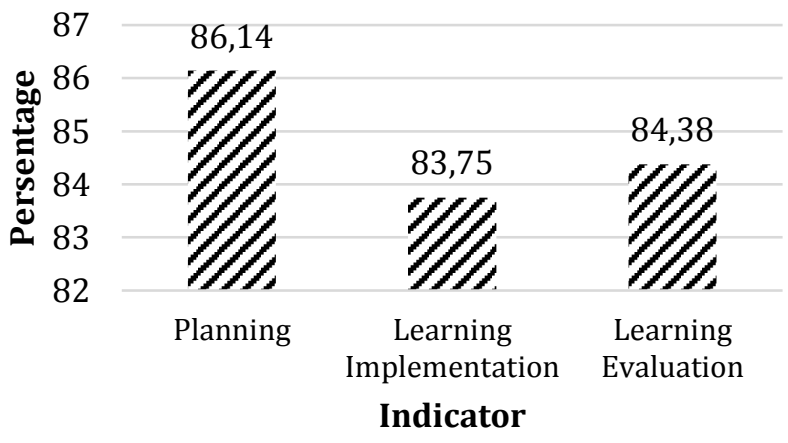

Figure 2 - Distribution of Average Value of Learning Quality Indicators

The data in Figure 2 show that the indicator of learning quality with the highest assessment is planning indicators with an average of 86.14. Although the lowest assessment indicators are learning implementation indicators with an average value of 83.75. Therefore, it can be concluded that the indicators of learning quality, namely planning, are well-executed, while the indicators of learning implementation and evaluation are not maximized.

Effect of Technology Literacy on the Quality of Learning in Primary Schools of Lentera Hati Islamic Boarding School. Based on the calculation results, the simple linear regression test results are obtained, as in Table 3. 
Table 3 - ANOVA Test Effect of $X_{1}$ on $Y$

\begin{tabular}{|l|l|l|l|l|l|l|}
\hline \multirow{2}{*}{ Model } & Unstandardized Coefficients & tcount & table & Sig. & Adjusted R \\
\cline { 2 - 7 } & B & Std. Error & & & & \\
\hline Constant & 29,333 & 10,825 & 2,710 & 2,086 & 0,013 & \\
\hline Technology Literacy & 0,723 & 0,223 & 3,236 & 2,086 & 0,004 & 0,311 \\
\hline
\end{tabular}

Table 3 shows the calculated value of 3.236 and greater than the value of $t$ Table 2.086 so that the hypothesis $(\mathrm{Ha})$ is accepted. The alternative hypothesis, therefore, has a positive effect on technological literacy on the learning quality at the primary school of Lentera Hati of Islamic boarding school. Data from Table 3 also shows the constant value (a) $=29.333$ and the regression coefficient (b) $=0.723$, so the linear regression equation is simply $\mathrm{Y}=29.333+0.723 \mathrm{X}_{1}$. This means that if technological literacy has increased by 1 , the quality of learning will increase by 0.723 , or for every increase of one technological literacy constant, this will be followed by an increase in the quality of learning by 0.723 . The adjusted $R$ squared value of 0.311 can be interpreted to mean that technological literacy has an effect of $31.1 \%$ on the quality of learning. 68.9\% is affected by other factors.

The author [9] argues that the availability of technology allows students to gain a richer experience during class by using multimedia simulations when learning a concept. This is the same as his statement [16] states that high-quality learning media can improve the quality of education and the presence of interesting media can improve the quality of learning.

Information technology mastery has now become part of the requirements of the competence of teachers, both in support of the performance of their tasks (planning preparation, presentation of learning, evaluation, and analysis of evaluation results) and as a means of finding and downloading learning resources. Technology is expected to become a unit in learning so that students become more active and independent. Of course, the quality of learning is expected to improve. Author [5] emphasizes that teachers are expected to equip themselves with different knowledge, techniques, and skills based on technology in today's educational world.

Even educational technology experts cite the role of technology in the quality of learning, which helps to increase the effectiveness and efficiency of teaching and learning processes. The application of technology in education makes the educational process more efficient in the learning process and more effective so that what is done with less time and energy can achieve goals [4]. For this, the development of learning using technology is very important and must be done by the teacher.

Authors [2] sees the greatest challenge in applying ICT in learning, namely the technical skills of teachers. "Both teachers and students learn new skills related to ICT". Thus, a teacher must have different skills that support his task in teaching. One of these skills is how a teacher can use technology as a learning medium [6]. The teacher can make interactive media creations and variations, create interactive learning CDs, power points, and computer media. Also, teachers should be able to identify which technology will be used when students are more efficient and efficient. This is consistent with [15] statement that to illustrate how each technology tends to play a different role in learning, students should consider what type of technology is used in the classroom.

Technology skills of Lentera Hati Elementary School Islamic boarding school teachers in the $2019 / 2020$ school year are classified as moderate, which is evidenced by the overall average literacy indicator for teacher technology reaching 75.5. The implementation of non-maximized indicators certainly has an impact on the ineffectiveness of technological literacy, resulting in sub-optimal learning quality. Based on observations, the teacher knows the technology, but applications and practices in learning should also consider considering the expected learning quality. Therefore, teachers of the Elementary School in Islamic boarding school Lentera Hati are expected to implement the indicators of technological literacy to the maximum. The higher the technological literacy, the better the quality of learning is expected.

The influence of technological literacy on the quality of learning is certainly due to the teachers of the Islamic boarding school Lentera Hati Elementary School who are reasonably good at implementing indicators of technological literacy. The findings of this study are consistent with the results of research conducted by $[8,24]$, which 
concluded that technological literacy has a positive and significant effect on the quality of learning.

In the study by [25] on Nigerian secondary school teachers, the lack of technical support in schools and the lack of expertise of teachers in the use of information and communication technologies are the main factors driving the willingness and confidence of hinder teachers in the use of information and communication technology.

The contribution of technology skills to the quality of learning in the Islamic boarding school Lentera Hati Elementary School contributes 31.1\% and the remaining $68.9 \%$ is influenced by other factors. Technology skills will be effective if the teacher can implement the indicators of technology skills. The indicators of technological literacy in this study are 1) technological knowledge, 2) technical skills, 3) interests, and attitudes.

\section{CONCLUSION}

Based on the results of the analysis and discussion, it can be concluded that there is a positive and significant influence between technological literacy on the quality of learning in primary school Lentera Hati of the Islamic boarding school. This is evident from the correlation coefficient rx1y value of 0723 and the determination coefficient $r^{2} x 1 y$ value of $31.1 \%$, so the higher the technological literacy, the higher the quality of learning.

\section{REFERENCES}

1. Ahmad, I. (2018). Proses Pembelajaran Digital dalam Era Revolusi Industri 4.0. Retrieved from http://mufidnilmada.staff.gunadarma.ac.id/Downloads/files/59974/07.+Materi+Paparan+Dire ktur+Jenderal+Pembelajaran+dan+Kemahasiswaan.pdf

2. Anderson, J., \& Glenn, A. (2003). Building Capacity of Teacher/Facilitator in Technology-Pedagogy Integration for Improved and Learning. Bangkok: UNESCO Bangkok.

3. Aqib, Z. (2010). Profesionalisme Guru Dalam Pembelajaran. Surabaya: Insan Cendekia.

4. Asmani, J. M. (2011). Tips Menjadi Guru Inspiratif Kreatif Dan Inovatif. Jogjakarta: DIVA Press.

5. Aziz, Abd. (2007). Tahap penggunaan teknologi maklumat sebagai pemudah komunikasi dalam proses pengajaran dan pembelajaran (P\&P) dalam kalangan pensyarah politeknik. Retrieved from http://eprints.uthm.edu.my/id/eprint/832/1/24_Pages_from_TAHAP_PENGGUNAAN_TEKNOL OGI_MAKLUMAT_SEBAGAI_PEMUDAH_KOMUNIKASI_DALAM_PROSES_PENGAJAR.pdf

6. Bahri, S. D \& Zein, A. (2006). Strategi Belajar Mengajar. Jakarta: Rineka Cipta.

7. Budiman, H. (2017). Peran teknologi Informasidan Komunikasidalam Pendidikan. Al-Tadzkiyyah: Jurnal Pendidikan Islam, 8(1), 31-43.

8. Elpira, B. (2018, February 8). Pengaruh Penerapan Literasi Digital terhadap Peningkatan Pembelajaran Siswa di SMP Negeri 6 Banda Aceh. Retrieved from https://repository.arraniry.ac.id/id/eprint/4331/1/Bella\%20Elpira.pdf

9. Fakultas Ilmu Keperawatan. (2012). ABC Asuhan Persalinan. Retrieved from http://library.unissula.ac.id/ucs/index.php?p=show_detail\&id=11129

10. Fauziah. (2015). Pengantar Teknologi Informasi dan Komunikasi SMP. Jakarta: Media Pusindo.

11. Hasratuddin. (2014). Pembelajaran Matematika Sekarang dan yang akan Datang Berbasis Karakter. Jurnal Didaktik Matematika, 1(2), 30-41.

12. Helterbran, V. R. (2008). Professionalism: Teachers Taking the Reins. The Clearing House, 81(3), 123-127.

13. Hernani dan Mudzakir, A. (2010). Pengaruh Pembelajaran Berbasis Literasi Sains Dan Teknologi Terhadap Keterampilan Proses Sains Siswa SMP. Jurnal Pendidikan Matematika dan Sains, 1, 2934. 
14. Juditha, C. (2017). Tingkat Literasi Teknologi informasi Komunikasi pada Masyarakat Kota Makassar. Jurnal Penelitian Komunikasi, 14(1), 41-52. doi: 10.20422/jpk.v14i1.167

15. Lei, J., \& Zhao, Y. (2007). Technology uses and student achievement: A longitudinal study. Computers \& Education, 49(2), 284-296. doi: 10.1016/j.compedu.2005.06.013

16. Munir, MIT. (2008). Kurikulum Berbasis TIK. Bandung: Alphabeta.

17. Musfiqon, H. M. (2012). Panduan Lengkap Metode Penelitian Pendidikan. Jakarta: PT. Prestasi Pustakarya.

18. Picton, I. (2019, April). Teachers' use of technology to support literacy in 2018. Retrieved from https://cdn.literacytrust.org.uk/media/documents/Teachers_Use_of_Technology_report.pdf

19. Pribadi, B.A. (2014). Pengembangan Program Tutorial Via Media Teknologi Video Conference Dalam Sistem Pendidikan Jarak Jauh (SPJJ). Jurnal Pendidikan Terbuka dan Jarak Jauh, 15(1), 111.

20. Qosthalani. (2019). Pendidikan Tanpa Kertas Abad 21. Bogor. Guepedia.

21. Setiadi, D. (2013). Pengembangan Model Pembelajaran Untuk Meningkatkan Kemampua Literasi Sains Peserta Didik SMP (Dissertation). Retrieved from http://repository.upi.edu/1832/1/D_PK_0807944_TITLE.pdf

22. Sugiyono. (2018). Metode Penelitian Pendidikan Pendekatan (Kuantitatif, Kualitatif dan R\&D). Bandung: Alfabeta.

23. Suminar, D. (2019). Penerapan Teknologi Sebagai Media Pembelajaran Pada Mata Pelajaran Sosiologi. Prosiding Seminar Nasional Pendidikan FKIP, 2(1), 774-783

24. Sunaengsih, C. (2016). Pengaruh Media Pembelajaran Terhadap Mutu Pembelajaran Pada Sekolah Dasar Terakreditasi A. Mimbar Sekolah Dasar, 3(2), 183-190.

25. Tella, A., Tella, A., Toyobo, O., Adika, L., \& Adeyinka, A. (2007). An Assessment of Secondary School Teachers Uses of ICTs: Implications for Further Development of ICT's Use in Nigerian Secondary Schools. The Turkish Online Journal of Educational Technology, 6(3), 1-13.

26. Tiharita, R. (2018). Optimalisasi Pemanfaatan Media Internet dalam Pembelajaran melalui Blended Learning. OIKOS Jurnal Kajian Pendidikan Ekonomi Dan Ilmu Ekonomi. doi: 10.23969/oikos.v2i1.917

27. Usman, S. (2014). Meningkatan Mutu Pendidikan Melalui Penerapan Manajemen Berbasis Sekolah. Jurnal Ilmiah DIDAKTIKA, 15(1), 13-31

28. Zulfiati, H. M. (2014). Peran dan Fungsi Guru Sekolah Dasar dalam Memajukan Dunia Pendidikan. Trihayu: Jurnal Pendidikan Ke-SD-an, 1(1), 1-4. 